\title{
Renal Disease Haemogram and Plasma Biochemistry in Green Iguana
}

\author{
Z. KNOTEK ${ }^{1}$, K. HAUPTMAN ${ }^{1}$, Z. KNOTKOVÁ ${ }^{2}$, P. HÁJKOVÁ ${ }^{1}$, F. TICHÝ $^{3}$ \\ ${ }^{1}$ Small Animal Clinic, ${ }^{2}$ Department of Physiology, ${ }^{3}$ Department of Anatomy, Histology and Embryology, \\ Faculty of Veterinary Medicine, University of Veterinary and Pharmaceutical Sciences Brno \\ Received January 17, 2002 \\ Accepted July 23, 2002
}

Abstract

Knotek Z., K. Hauptman, Z. Knotková, P. Hájková, P., F. Tichý: Renal Disease Haemogram and Plasma Biochemistry in Green Iguana. Acta Vet. Brno 2002, 71: 333-340.

Haemogram and plasma biochemistry were investigated in 20 green iguanas suffering from renal disease. Anorexia was present in $15(75 \%)$ patients, frequently associated with limited hind leg movement $(50 \%)$. Constipation as a secondary complication of the colon compression by the enlarged kidneys was observed in $8(40 \%)$ iguanas. Swelling of the hind legs appeared in 6 iguanas $(30 \%)$. The post-mortem examination revealed renal oedema, tubular necrosis, tubular and/or interstitial nephritis, renal gout with tophi formation in $62.5 \%, 62.5 \%, 40.0 \%$ and $37.5 \%$ iguanas, respectively. Evaluation of the haemogram revealed in these patients heterophilia, eosinophilia and azurophilia (means 5.3, 0.6 and $0.9 \mathrm{G} / 1$, respectively), the number of heterophils and eosinophils have increased significantly $(p<0.05)$. Mean values for the packed cell volume, RBC counts, WBC counts, basophils and monocytes $(0.351 / 1,1.2 \mathrm{~T} / 1,12.8,0.4$ and $0.8 \mathrm{G} / 1$, respectively) were within physiological ranges, the number of lymphocytes $(4.7 \mathrm{G} / 1)$ was lower $(p<0.05)$ than normal ranges for healthy iguanas. Mean values for total protein, ALT, GGT, glucose, cholesterol, calcium and potassium in plasma were within physiological ranges for green iguanas. The concentrations of creatinine, AST, uric acid and phosphorus $(61.07 \mu \mathrm{mol} / 1,5.02 \mu \mathrm{kat} / 1,306.70 \mu \mathrm{mol} / \mathrm{l}$ and 5.95 $\mathrm{mmol} / \mathrm{l}$, respectively) in green iguanas with renal disease were increased $(p<0.05)$, whereas the activity of ALP $(0.38 \mu \mathrm{kat} / \mathrm{l})$ was decreased $(p<0.05)$. As a consequence of the elevated phosphorus levels the P:Ca ratio has increased significantly to $3.52(p<0.05)$. Evaluation of the haemogram as well as plasma biochemistry may be regarded as a useful tool in the diagnosis of renal failure in green iguanas.

Reptiles, kidney, gout, nephritis

Renal disease is a condition that is frequently diagnosed post-mortem in different species of herbivorous lizards. There are many different factors that can predispose to renal disease in reptiles. Chronic metabolic problems caused in green iguanas by basic mistakes in their nutrition in captivity as well as poor husbandry are frequently observed and result in different forms of renal disease (Wright and Cooper 1981; Troyer 1984). Renal failure and metastatic calcification are major causes of death of adult iguanas in captivity (B oyer et al. 1996; Ball et al. 1999). Clinical signs associated with renal disease may vary, but usually include lethargy, inappetence, depression, general weakness, tremor and paresis (B oyer et al. 1996; Antin off 2000). The process is usually chronic and therefore a gradual reduction in appetite and activity, ataxia, problems with fecundity and fertility, retarded weight gain or gradual weight loss could be observed by the owner.

There is still a paucity of information concerning the pathogenesis of renal disease in reptiles. Renal disease in the form of glomerular, tubular and/or interstitial failure is frequently missed by the clinician ( $Z_{w}$ art 1992). Acute inflammation of the kidney can result in a dramatic heterophilia and monocytosis (azurophilia), whereas chronic bacterial nephritis causes minor elevations of the total white blood cell count. Acute renal disease as a primary disease may be associated with elevations of several enzymes including AST (aspartate aminotransferase), GGT ( $\gamma$-glutamyltransferase), ALP (alkaline phosphatase),

Address for correspondence:

Doc. MVDr. Z. Knotek, CSc.

Small Animal Clinic

University of Veterinary and Pharmaceutical Sciences

Palackého 1-3, CZ - 61242 Brno, Czech Republic
Phone: +420541562382

e-mail: knotekz@

http://www.vfu.cz/acta-vet/actavet.htm 
ALT (alanine aminotransferase) and LDH (lactate dehydrogenase). Chronic renal disease in reptiles is associated with elevation of plasma concentrations of phosphorus and uric acid and alteration of the phosphorus:calcium ratio (B oyer et al. 1996).

The aim of this study was to characterise the haematological profile and plasma biochemistry in green iguanas with renal disease and to establish the value of these laboratory methods for diagnostic purposes.

\section{Materials and Methods}

Animals

A total of 20 green iguanas suffering from chronic disease were included in the study. Patients were referred to Small Animal Clinic, Faculty of Veterinary Medicine, by private veterinarians in the Czech Republic. The first step consisted of a thorough anamnestic record taking (age of the animal at the time of first clinical signs, duration of the disease, associations with the environmental factors and feed intake, health status of other animals kept). Such signs as the current temperament of the lizard, type of locomotion, appetite, faeces and urine character, nasal discharge and hind leg status were evaluated. On the basis of anamnestic data, as well as the physical examination of the patient, iguanas were characterised individually as anorectic lizard (AL), lizard with limited hind leg locomotion without any visible bone deformations (LHLL) and lizard with hind leg swellings as a consequence of metabolic bone disease (MBD).

Blood collection

Blood samples for the determination of biochemical as well as haematological profiles were collected from the ventral coccygeal vein approximately one-third of the tail length from the cloaca (Redrobe and MacDonald 1999). The $23 \mathrm{G} \times 1$ Luer needle was inserted at an angle of 30 to $60^{\circ}$ and advanced until the needle hit the vertebral body. A total of $0.5-1 \mathrm{ml}$ of blood was collected.

Haemogram

Packed cell volume (PCV) was measured using microhematocrit capillary tubes. Total red blood cell and white blood cells counts were performed manually, using a hemocytometer with Natt and Herrick's solution. Blood smears were prepared immediately, using a coverslip technique, and were air dried. The Pappenheim method of biphasic staining with May-Grünwald and Giemsa-Romanowski stain was used. Differential leukocyte counts were assessed by enumeration of 200 cells in each smear. This was done in 15 iguanas. The smears were viewed by the Jenamed 250 CF microscope (Carl Zeiss, Jena, Germany) connected with the camera 3-CCD HV-C20 (Hitachi, Denshi, Japan).

Plasma biochemistry

Blood samples of each iguana in heparinised tubes (Heparin Léčiva inj., Prague) were centrifuged and the plasma removed. The plasma samples were transported to the laboratory of Faculty of Veterinary Medicine and analysed on the day of collection. All plasma biochemical assays were performed using automated analyzers - the concentration of total protein (TP), creatinine, glucose, uric acid, blood urea nitrogen (BUN), cholesterol, phosphorus (P) and activities of alkaline phosphatase (ALP), alanine aminotransferase (ALT), aspartate aminotransferase (AST), $\gamma$-glutamyltransferase (GGT) were performed by CobasMira analyzer (Roche); plasma concentration of calcium $(\mathrm{Ca})$ and potassium $(\mathrm{K})$ was performed by Atomspec analyzer (Hilger 1550).

\section{Histopathology}

Biopsy specimens for the histological examination, obtained during general necropsy of the dead iguanas, were preserved in $10 \%$ neutral buffered formalin for 12 to $24 \mathrm{~h}$ and processed in a standard paraffin technique. Renal tissue sections of $4-6 \mu \mathrm{m}$ were stained using hematoxylin-eosin. Differentiation of inflammatory lesions, determination of individual types of inflammation, classification of neoplasia, and preliminary diagnosis of bacterial diseases were performed in a specialised laboratory of the Department of Anatomy, Histology and Embryology. Documentation of the histological pictures were evaluated using the magnification of 100 to 1000 and an Olympus BX-40 microscope equipped for photo-documentation by a digital camera Olympus $2000 \mathrm{Z}$.

Statistical analyses

Statistical analyses of haematological and plasma biochemical values were performed using the Stat Plus software (Stat Plus, version 1.01, 1990, VÚVeL Brno, Czech Republic).

\section{Results}

Clinical symptoms in iguanas with renal disease and the effect of treatment

Clinical signs associated with renal disease in the group of twenty iguanas have varied (Table 1). Anorexia was present in $15(75 \%)$ patients, frequently associated with limited

Basic char

\begin{tabular}{|c|c|c|}
\hline Animal & Subspecies & \{ \\
\hline 1 & Iguana i. rhinolopha & \\
\hline 2 & Iguana i. rhinolopha & \\
\hline 3 & Iguana i. rhinolopha & \\
\hline 4 & Iguana i. rhinolopha & \\
\hline 5 & Iguana i. rhinolopha & \\
\hline 6 & Iguana i. rhinolopha & \\
\hline 7 & Iguana i. iguana & \\
\hline 8 & Iguana i. iguana & \\
\hline 9 & Iguana i. iguana & \\
\hline 10 & Iguana $i$. iguana & \\
\hline 11 & Iguana i. iguana & \\
\hline 12 & Iguana i. iguana & \\
\hline 13 & Iguana i. iguana & \\
\hline 14 & Iguana i. rhinolopha & \\
\hline 15 & Iguana i. iguana & \\
\hline 16 & Iguana i. rhinolopha & \\
\hline 17 & Iguana i. rhinolopha & \\
\hline 18 & Iguana i. iguana & \\
\hline 19 & Iguana i. iguana & \\
\hline 20 & Iguana i. rhinolopha & \\
\hline
\end{tabular}

${ }^{1}$ AL (anorectic lizard), LHLL (limite

hind legs movement $(50 \%)$. Constipation as a secondary cc was observed in $8(40 \%)$ iguan therapy by gastric tube (Ring, minimal volume of fluid $20 \mathrm{ml}$

Haematological ।

\begin{tabular}{|l|c|c}
\hline \multirow{2}{*}{ Parameters } & \multirow{2}{*}{ Units } & \\
\cline { 3 - 3 } & & Min. \\
\hline PCV & $1 / 1$ & 0.30 \\
\hline RBC & T/1 & 0.80 \\
\hline Total WBC & G/1 & 7.60 \\
\hline Heterophils & G/1 & 4.20 \\
\hline Azurophils & G/1 & 0.30 \\
\hline Lymphocytes & G/1 & 1.20 \\
\hline Monocytes & G/1 & 0.10 \\
\hline Eosinophils & G/l & 0 \\
\hline Basophils & G/l & 0 \\
\hline
\end{tabular}

${ }^{1}$ Harr et al. (2001) a-a $(p<0.05)$ 
in water by gastric tube) and cloaca-colon washing with lukewarm water. Eight of $20(40 \%)$ green iguanas died in spite of the treatment during the study. The results of general necropsies and histopathologic examination of the renal tissues are reviewed in the table (Table 4).

\section{Haemogram}

PCV, RBC counts, WBC counts and differential lekocyte counts in the peripheral blood of healthy iguanas and those with renal disease are reviewed in Table 2 . We have revealed heterophilia, eosinophilia and azurophilia. The numbers of heterophils and eosinophils increased significantly $(p<0.05)$. Mean values for PCV, RBC counts, WBC counts, basophils and monocytes were within physiological ranges, the number of lymphocytes was significantly lower than normal ranges for healthy iguanas $(p<0.05)$.

Table 3

Blood plasma biochemistry values in healthy iguanas and iguanas with renal disease

\begin{tabular}{|c|c|c|c|c|c|c|c|}
\hline \multirow[t]{2}{*}{ Parameter } & & \multicolumn{3}{|c|}{$\begin{array}{l}\text { Green iguanas with renal disease } \\
\qquad \mathrm{n}=20\end{array}$} & \multicolumn{3}{|c|}{ Healthy green iguanas ${ }^{1}$} \\
\hline & & Min. & Max. & Mean \pm SD & Min. & Max. & Mean \\
\hline Total protein & $\mathrm{g} / 1$ & 29.10 & 78.00 & $53.51 \pm 15.96$ & 22.0 & 78.2 & 56.1 \\
\hline Glucose & $\mathrm{mmol} / \mathrm{l}$ & 0.23 & 25.43 & $10.07 \pm 6.81$ & 8.3 & 16.5 & 12.1 \\
\hline Uric acid & $\mu \mathrm{mol} / 1$ & 44.00 & 815.60 & $306.70 \pm 212.88^{a}$ & 70.4 & 145.3 & $89.3^{\mathrm{a}}$ \\
\hline Creatinine & $\mu \mathrm{mol} / 1$ & 21.90 & 91.10 & $61.07 \pm 24.78^{b}$ & 8.8 & 66.3 & $35.2^{b}$ \\
\hline BUN & $\mathrm{mmol} / \mathrm{l}$ & 0.46 & 2.88 & $1.35 \pm 0.83$ & 0.1 & 2.5 & 0.9 \\
\hline ALP & $\mu \mathrm{kat} / 1$ & 0.07 & 1.27 & $0.38 \pm 0.33^{c}$ & 0.7 & 4.9 & $2.6^{\mathrm{c}}$ \\
\hline ALT & $\mu \mathrm{kat} / \mathrm{l}$ & 0.08 & 2.34 & $0.74 \pm 0.64$ & $<0.1$ & 1.2 & 0.8 \\
\hline $\mathrm{AST}$ & $\mu \mathrm{kat} / \mathrm{l}$ & 0.10 & 19.99 & $5.02 \pm 5.82^{d}$ & $<0.1$ & 1.6 & $1.2^{\mathrm{d}}$ \\
\hline GGT & $\mu \mathrm{kat} / 1$ & 0.02 & 0.33 & $0.13 \pm 0.17$ & $<0.1$ & $<0.1$ & $<0.1$ \\
\hline Cholesterol & $\mathrm{mmol} / \mathrm{l}$ & 0.84 & 11.20 & $5.29 \pm 3.62$ & 2.5 & 8.9 & 6.3 \\
\hline $\mathrm{K}$ & $\mathrm{mmol} / \mathrm{l}$ & 3.87 & 4.52 & $4.18 \pm 0.33$ & 1.3 & 5.2 & 3.2 \\
\hline $\mathrm{Ca}$ & $\mathrm{mmol} / \mathrm{l}$ & 0.87 & 3.38 & $2.06 \pm 0.78$ & 2.2 & 3.5 & 3.3 \\
\hline $\mathrm{P}$ & $\mathrm{mmol} / \mathrm{l}$ & 1.61 & 11.90 & $5.95 \pm 3.21^{\mathrm{e}}$ & 1.4 & 3.1 & $1.6^{\mathrm{e}}$ \\
\hline
\end{tabular}

${ }^{1}$ Knotek et al. (1999)

a-a $(p<0.05) \quad$ b-b $(p<0.05) \quad$ c-c $(p<0.05) \quad$ d-d $(p<0.05) \quad$ e-e $(p<0.05)$

\section{Plasma biochemistry}

Results of plasma biochemistry analyses of healthy iguanas and iguanas with renal disease are summarised in Table 3. Mean values for total protein, ALT, GGT, glucose, cholesterol, potassium and calcium were within physiological for healthy green iguanas. Mean concentrations of creatinine, uric acid, phosphorus and AST increased significantly $(p<0.05)$, mean activity of ALP decreased significantly $(p<0.05)$. The P:Ca ratio was changed dramatically $(p<0.05)$ as a consequence of the altered phosphorus plasma levels.

\section{Discussion}

Renal disease is a common problem of reptiles kept in captivity and a major cause of reptile mortality (Antinoff 2000; Kölle and Hoffmann, 2001). The clinical signs of severe renal failure in a group of twelve green iguanas included anorexia, lethargy, tremors, dyschezia, bloat and paresis in $75 \%, 66 \%, 66 \%, 58 \%, 25 \%$ and 16\%, respectively (B oyer
Histopathologic:

\begin{tabular}{|c|c|}
\hline Animal & Subspecies \\
\hline 1 & Iguana i. rhinolopha \\
\hline 2 & Iguana i. iguana \\
\hline 3 & Iguana i. iguana \\
\hline 4 & Iguana i. iguana \\
\hline 5 & Iguana i. iguana \\
\hline 6 & Iguana i. iguana \\
\hline 7 & Iguana i. iguana \\
\hline 8 & Iguana $i$. rhinolopha \\
\hline
\end{tabular}

et al. 1996). Anorexia was th renal disease in the present stu leg paresis was present in $50 \%$ as a consequence of colon co Swelling of the hind legs whicl Boyer et al. (1996) describer $66 \%$ of green iguanas. In the 1 any of the patients with rena lizards in the period of fast grc study). The treatment based or was effective almost in all cas; tremor questionable. We concl leg swelling and limited locon

The diagnostic value of ur: urinalysis in reptiles as a va Hoffmann 2000, 2001). Tr practical value of this method cannot concentrate urine $(\mathrm{Mi}$ ] from the stored urine occurs is 1998). In the reptilian cloaca microbial flora and metabol different species of iguanid liz 
by nasal salt glands (Frye and Townsend 1993). It means that, for instance, urine osmolarity does not correlate with kidney function (Miller 1998). Unlike ureotelic mammals, uricotelic reptiles produce variable concentrations of urea, depending on the level of dehydration. The serum urea nitrogen and creatinine may not elevate even in renal failure (Divers et al. 1996). However, Boyer et al. (1996) have observed altered concentrations of creatinine as well as glucose, AST, ALT and potassium in the peripheral blood of green iguanas with severe renal failure. In the group of twenty green iguanas in this study, mean values for total protein and potassium in plasma were within physiological ranges (Knotek et al. 1999). The concentrations of creatinine and activity of AST were increased significantly. These findings are in accordance with B oyer et al. (1996), even with some differences in the physiological range. The plasma activity of ALP was decreased; mean values for ALT, GGT, glucose, cholesterol and calcium were within normal ranges for healthy green iguanas (Knotek et al. 1999). It is felt that serum concentrations of uric acid, phosphorus and calcium could be useful indicators of renal injury or insufficiency (Divers et al. 1996; Köhler 1996; Mader 1996; Divers 1997; Miller 1998; Kölle and Hoffmann 2001). The normal uric acid concentrations in the blood serum of green iguanas are within the interval of 70.2-145.3 $\mu \mathrm{mol} / \mathrm{l}$. Elevated serum phosphorus concentrations and changes in the $\mathrm{P}: \mathrm{Ca}$ ratio may occur in renal insufficiency. The normal phosphorus and calcium concentrations in the blood serum of iguanas are 1.4$3.1 \mathrm{mmol} / \mathrm{l}$ and $2.5-3.5 \mathrm{mmol} / \mathrm{l}$, respectively (Knotek et al. 1999). Elevated uric acid levels may indicate aminoglycoside intoxication, septicaemia and nephrocalcinosis (Zw art 1992). However, uric acid levels can be normal in reptiles suffering primarily from renal disease. While an elevated uric acid still remains a reliable indicator of renal pathology, it may not elevate until the later stages of renal disease (Antin off 2000). The $\mathrm{P}: \mathrm{Ca}$ ratio seems to be a much more sensitive parameter. This ratio is altered at an earlier stage of renal disease as compared to uric acid (Kölle and Hoffmann 2001). The pathological condition of kidneys results frequently in profound calcium metabolism disturbance (Zwart 1992; Miller 1998). Renal disease is assumed when the plasma concentration of phosphorus is higher than plasma calcium concentration, and when both parameters are altered significantly (Kölle and Hoffmann 2001). Boyer et al. (1996) observed that the mean values for calcium were lower than normal range for healthy iguanas. We have seen the same tendency, however without statistical significance. We have confirmed, in accordance with the authors cited, increased plasma levels of uric acid and phosphorus. As a consequence of the altered phosphorus levels the P:Ca ratio was changed significantly in green iguanas with renal disease. This is in accordance with results published by Divers (2000). We recommend to examine the plasma concentrations of uric acid, phosphorus and calcium (and to calculate the $\mathrm{P}: \mathrm{Ca}$ ratio) in all anorectic green iguanas, especially if chronic renal disease is suspected to be the cause.

B oyer et al. (1996) observed leukocytosis, heterophilia and high PCV in five iguanas with renal failure. At our present study the mean values for PCV, RBC counts and WBC counts were within normal ranges for iguanas. One potential problem is that the haematological profile established for healthy green iguanas is laboratory-specific. Leukocytosis, heterophilia and high PCV described by B oyer et al. (1996) were 17.2 G/1, $8.3 \mathrm{G} / 1$ and $0.37 \mathrm{l} / 1$, respectively. The upper limit of leukocytes in the peripheral blood as is seen on the haematologic reference range for clinically normal green iguanas published by other authors is $10.0-25.2 \mathrm{G} / \mathrm{l}$ (Divers et al. 1996; Harr et al. 2001). It is possible that many healthy iguanas could be included mistakenly into the leukocytosis group. A similar complication could have occurred in the case of PCV evaluation, as the reference ranges published are 0.25 - 0.47 1/l (Divers et al. 1996; Harr et al. 2001). The number of heterophils in the peripheral blood of iguanas with renal failure described by B oyer et al.
(1996) seems to be high enou. published compilation of haer Mean values for heterophil: significantly elevated. We fc number of basophils and mon lymphocytes was lower than percentage of lymphocytes wa (1996). We suppose that high could accompany chronic ren phenomenon has yet to be exc accompanies all cases of rena] infectious aetiology.

Histopathologic changes of be normal or have mild change necrosis, interstitial nephritis fibrosis (Antinoff 2000). T reptiles are nephritis secondal renal gout with renal oedema present study renal oedema ha: necrosis was confirmed in 62 . (1992) that tubulonephrosis is extensive tubular and/or inter mortem in the present study, have been published by B oy $\epsilon$ subsequent to general diseas combined with the absence of 1 is the common end-situation o

Our results confirm the idea be used as a practical diagno Nevertheless, further investig practical diagnostic methods a

\section{Hemogram a biochemický p}

Do sledování bylo zahrnuto ledvin. U 15 (75\%) pacientů pohybu pánevních končetin (5 byla pozorována u $8(40 \%)$ lę $\%)$. Postmortální vyšetření or tubulární a intersticiální nefrit $62.5 \%, 40.0 \%$ and $37.5 \%$ heterofilii, eozinofilii a azu a eozinofilních granulocytů významnosti $(p<0.05)$. Hen granulocytů a monocytů $\mathrm{v}$ per v rozmezí hodnot zdravých le krevní plazmě $(61.07 \mu \mathrm{mol} / 1$, : výrazně zvýšeny $(p<0.05)$, : Průměrné hodnoty koncentra GGT v krevní plazmě se po] zvýšení koncentrace fosforu 
hemogramu a stanovení biochemického profilu krevní plazmy u leguánů zelených je př́nosem v intravitální diagnostice onemocnění ledvin.

\section{Acknowledgements}

This project was supported by the grant of the Ministry of Education, Youth and Physical Education of the Czech Republic (No. 161/700002). The authors wish to thank to Dr. W.G.V. Lewis (South Beech Veterinary Surgery, Wickford) and Dr. M. Deutschland (Berlin) for their comments and kind revision of the text.

\section{References}

ANTINOFF, N 2000: Renal Disease in the Green Iguana (Iguana iguana). Proc. Association Reptilian and Amphibian Veterinarians, pp. 61-63

BALL, RL, DUMONCEAUX, G, MacDONALD C 1999: Hypetrophic Osteopathy associated with Renal Gout in a Green Iguana (Iguana iguana). Proc. Association Reptilian and Amphibian Veterinarians, 5. - 9. 10. 1999, Columbus, pp. 49-50

BOYER, TH, GETZY, D, VAP, L, INNIS, C 1996: Clinicopathologic Findings of Twelve Cases of Renal Failure in Iguana iguana. Proc. Association Reptilian and Amphibian Veterinarians, 24. - 27. 8. 1996, Tampa, p. 113

DIVERS, SJ, REDMAYNE, G, AVES, EK 1996: Haematological and biochemical values of 10 green iguanas (Iguana iguana). Vet Rec 138: 203-205

DIVERS, SJ 1997: Clinician's approach to renal disease in lizards. Proc. Association Reptilian and Amphibian Veterinarians, pp. 5-11

DIVERS, SJ 2000: Reptilian renal and reproductive disease diagnosis. In: Fudge, AM Laboratory medicine: avian and exotic pets. WB Saunders, Philadelphia, pp. 217-219

FRYE, FL, TOWNSEND, W 1993: Iguanas. A guide to their biology and captive care. Krieger Publishing Comp., Malabar, $145 \mathrm{p}$.

HARR, KE, ALLEMAN, R, DENNIS, PM, MAXWELL, LK, LOCK, BA, BENNET, RA, JACOBSON, ER 2001: Morphologic and cytochemical characteristics of blood cells and hematologic and plasma biochemical reference ranges in green iguanas. J Am Vet Med Assoc 218: 915-921

KNOTEK, Z, KNOTKOVÁ, Z, HALOUZKA, R, MODRY, D, HÁJKOVÁ, P 1999: Diseases of Reptiles (Nemoci plazů), ČAVLMZ, Brno, 275 p. (in Czech)

KÖHLER, G 1996: Krankheiten der Reptilien und Amphibien. Eugen Ulmer Verlag, Stuttgart, 166 p.

KÖLLE, P, HOFFMANN, R 2000: Urine Analysis in Tortoises. Proc. $3^{\text {rd }}$ EAZWV Scientific Meeting, 31.5. 4.6.2000, Paris, pp. 287- 289

KÖLLE, P, HOFFMANN, R 2001: Renal Diseases in Reptiles: Diagnostic Tools. Proc. Abstr. EAZA Scientific Meeting, 23.- 26. 5. 2001, Rotterdam, pp. 67- 69

MADER, DR 1996: Gout. In: Mader, DR Reptile Medicine and Surgery. W. B. Saunders, Philadelphia, pp. $374-$ 379

MILLER, HA 1998: Urinary Diseases of Reptiles: Pathophysiology and Diagnosis. In: Fudge, AM Seminars in Avian and Exotic Pet Medicine, Renal Diseases, WB Saunders, Philadelphia, 7: 93-103

REDROBE, S, MacDONALD, J 1999: Sample collection and clinical pathology of reptiles. Veter Clin North Amer - EAP 2: 709-730

STEIN, G 1996: Hematologic and blood chemistry values in reptiles. In: Mader, DR Reptile Medicine and Surgery. WB Saunders, Philadelphia, pp. 473-483

TROYER, K 1984: Diet selection and digestion in Iguana iguana: The importance of age and nutrient requirements. Oecologia 61: 201-207

WRIGHT, RK, COOPER, EL 1981: Temperature effects on ectotherm immune responses. Dev Comp Immunol, Suppl 5, 1: 117-122

ZWART, P 1992: Urogenital System. In: Beynon, PH, Lawton, MPC, Cooper, JE Manual of Reptiles. BSAVA, Cheltenham, pp. 117-12 